\title{
Profile and Severity of the Patients of Intensive Care Units: Prospective Application of the APACHE II Index
}

Eliane Regina Ferreira Sernache de Freitas ${ }^{1}$

This study aimed to understand the profile and severity of patients in physiotherapy treatment after their admission to the intensive care unit (ICU) by applying the APACHE II index. One hundred and forty six subjects, with a mean age of $60.5 \pm 19.2$ years, were evaluated. The APACHE II index was applied in the first 24 hours to evaluate the severity and mortality risk score. Patients were monitored until hospital discharge or death. The mean APACHE II score was $20 \pm 7.3$ with an estimated risk of death of $32.4 \%$ and observed mortality of $58.2 \%$. The mean hospital stay was $27.8 \pm 25.2$ days. The patients in physiotherapy at the institution studied were predominantly male, elderly, from the emergency service for treatment (non-surgical), and had clear severity, suggested by the APACHE II score and the observed mortality.

Descriptors: APACHE; Mortality; Intensive Care Units.

\footnotetext{
${ }^{1}$ Physical Therapist, Ph.D. in Health Sciences, Adjunct Professor, Universidade Norte do Parana (UNOPAR), PR, Brazil. E-mail: elianefe@sercomtel.com.br.
}

Corresponding Author:

Eliane Regina Ferreira Sernache de Freitas Universidade Norte do Paraná (Unopar)

Rua: Rua Paris, 675

Jardim Piza

CEP: 86041-140 Londrina, PR, Brasil

E-mail: elianefe@sercomtel.com.br 


\title{
Perfil e gravidade dos pacientes das unidades de terapia intensiva: aplicação prospectiva do escore APACHE II
}

Este estudo teve como objetivo conhecer o perfil e a gravidade de pacientes assistidos pela fisioterapia, após o seu ingresso nas unidades de terapia intensiva (UTI), através da aplicação do escore APACHE II. Avaliou-se 146 indivíduos com média de idade de $60,5 \pm 19,2$ anos. O escore APACHE II foi aplicado nas primeiras $24 \mathrm{~h}$ para avaliação da gravidade e pontuação do risco de mortalidade. Os pacientes foram acompanhados até o momento da alta hospitalar ou óbito. O escore APACHE II médio foi de $20 \pm 7,3$ com risco estimado de morte de $32,4 \%$ e mortalidade observada de $58,2 \%$. A média de permanência hospitalar foi de $27,8 \pm 25,2$ dias. Nos pacientes assistidos pela fisioterapia da instituição investigada, o predomínio foi do sexo masculino, idosos, provenientes do pronto atendimento para tratamento clínico (não cirúrgico) e que apresentam nítida gravidade, sugerida pelo escore APACHE II e pela mortalidade observada.

Descritores: APACHE; Mortalidade; Unidades de Terapia Intensiva.

\section{Perfil y gravedad de los pacientes de las unidades de terapia intensiva: aplicación prospectiva del puntaje APACHE II}

\begin{abstract}
Este estudio tuvo como objetivo conocer el perfil y la gravedad de pacientes asistidos por la fisioterapia, después de su ingreso en las unidades de terapia intensiva (UTI), a través de la aplicación del puntaje APACHE II. Se evaluaron 146 individuos con promedio de edad de 60,5 $\pm 19,2$ años. El puntaje APACHE II fue aplicado en las primeras $24 \mathrm{~h}$ para evaluar la gravedad y dar puntuación al riesgo de mortalidad. Los pacientes fueron acompañados hasta el momento del alta hospitalaria o de la muerte. El puntaje APACHE II promedio fue de $20 \pm 7,3$ con riesgo estimado de muerte de $32,4 \%$ y mortalidad observada de 58,2\%. El promedio de permanencia hospitalaria fue de 27,8 25,2 días. En los pacientes asistidos por la fisioterapia de la institución investigada, el predominio fue del sexo masculino, ancianos, provenientes de la atención rápida para tratamiento clínico (no quirúrgico) y que presentan nítida gravedad, sugerida por el puntaje APACHE II y por la mortalidad observada.
\end{abstract}

Descriptores: APACHE; Mortalidad; Unidades de Terapia Intensiva.

\section{Introduction}

The introduction of new treatments, technological advances, increasing life expectancy and the growth of chronic diseases that require intensive care at some point, are factors that have determined the rapid evolution of new specialties ${ }^{(1)}$.

The shortage of beds in intensive care units (ICU), forced to choose patients who are already dependent on vasopressors and/or mechanical ventilation, exacerbates the problem and delays the arrival of other patients, a difficult situation to contend with in wards with higher risk of death This framework selects extremely severe patients as applicants for places in the ICUs of the institutions, creating the risk of high rates of hospital mortality. Thus, some studies have addressed important issues related to the profile and severity of ICU patients ${ }^{(3-4)}$.

The performance of the ICU must be evaluated within the overall context of health care workers and professionals who are part of the institution, developing evaluation mechanisms in the field of intensive care, which are recognized in the literature and accepted by the scientific community, in order to assess, develop and improve the routine protocols. Strategies have been described and implemented by researchers and health professionals, in order to establish standardized behavior and improve the quality of health care ${ }^{(5-6)}$. 
The APACHE II index (Acute Physiology and Chronic Health Evaluation) is a form of evaluation and classification of the index of disease severity, and mainly aims at the quantitative description of the degree of organic dysfunction in critically ill patients, severity being translated into a numeric value from the existing clinical and laboratory alterations or the type/number of procedures used(7).

The APACHE II index values calculated at admission of the patient to the ICU, have been used to determine their severity and thus, together with other factors, identify the severity and the predictors of mortality in order to direct the assistance of health professionals ${ }^{(8)}$.

The hospital where the study was conducted is characterized by the complexity of the patients it cares for, having a physiotherapy service providing daily care to patients, by medical appointment. Considering the severity of the clinical symptoms of patients admitted to ICUs, this study was designed to identify the profile and severity of these patients in physiotherapy with the application of the APACHE II index, with regard to their demographic characteristics, origin of admission and the rate of mortality in hospital. Other parameters were evaluated in order to better understand the patient's length of stay in the ICU and the evolution of their clinical conditions in relation to their stay on the ward.

\section{Method}

This is an observational, prospective study and was conducted with patients hospitalized in ICUs, undergoing physiotherapy in a philanthropic hospital, located in the State of Parana, Brazil, from August to December 2007.

The project was approved by the Research Ethics Committee of the institution (Report $n^{\circ} 213 / 2006$ ) and, after explanation of the objectives and how the study would be conducted, obtained free prior informed consent from the participants. If the patient was not able to sign the consent, a family member could give authorization.
The physiotherapy service of the institution assists patients in the ICU, by medical referral, with three daily treatment sessions (morning - afternoon - evening). When they are transferred to the ward, these patients receive treatment daily in two sessions, continuing the assistance provided in the ICU.

The hospital keeps computerized medical records, which include information on demographic data and the examinations carried out on inpatients.

The APACHE II index, as an index of prognosis in the first 24 hours after ICU admission, was applied to evaluate the clinical severity and estimated mortality in three groups: clinical treatment, emergency surgery and elective surgery. The following data was recorded: sex, age, origin of the patient (emergency service - ES, the emergency service or ward), length of ICU stay, length of stay in the ward after transfer from ICU, readmission to the ICU and hospital discharge and mortality (ICU and ward).

We also assessed the risk of mortality estimated by APACHE II and compared this with the observed mortality. It is important to remember that, after the completion of the registration of the patients, they continued to be monitored until hospital discharge or death for the completion of the study.

Associations were evaluated by calculating the correlation coefficients of determination and significance, using the Statistical Package for Social Science (SPSS) version 12.0 and Bioestat version 4.0.

\section{Results}

Two hundred and fifty one patients were registered for physiotherapy in the ICUs, of these, 105 were excluded due to lack of data for evaluation of the APACHE II index or due to discharge or death within the first 24 hours.

Of the 146 patients studied, 58.9\% were male, the mean age was $60.5 \pm 19.2$ years, with a minimum age of 12 and a maximum of 95 years (Table 1 ) with $58.2 \%$ aged over 60 years.

Table 1 - Clinical and demographic data of the study population $(n=146)$. Londrina, PR, 2007

\begin{tabular}{|c|c|c|c|c|c|}
\hline Characteristics & ICU-1 (n=39) & ICU-2 (n=16) & ICU-3 (n=56) & ICU-4 (n=35) & Total $(n=146)$ \\
\hline \multicolumn{6}{|l|}{ Sex } \\
\hline Male & $21(53.8)$ & $11(68.8)$ & $30(53.6)$ & $24(68.6)$ & $86(58.9)$ \\
\hline Female & $18(46.2)$ & $5(31.2)$ & $26(46.4)$ & $11(31.4)$ & $60(41.1)$ \\
\hline Age (mean \pm sd) (range) & $60.6 \pm 18.4(15-93)$ & $65.1 \pm 16.9(32-85)$ & $65.1 \pm 16.5(26-95)$ & $50.9 \pm 22.2(12-90)$ & $60.5 \pm 19.2(12-95)$ \\
\hline APACHE II Score (mean \pm sd) (range) & $18.1 \pm 7.5(5-33)$ & $23.4 \pm 5.5(16-31)$ & $22.1 \pm 7.2(4-41)$ & $17.1 \pm 6.4(6-35)$ & $20 \pm 7.3(4-41)$ \\
\hline Risk (\%) (sd) (range\%) & $28.8 \pm 20.1(7-73)$ & $42.4 \pm 22.0(12-73)$ & $39.2 \pm 21.1(1-85)$ & $20.8 \pm 18.1(3-88)$ & $32.4 \pm 21.8(1-88)$ \\
\hline Time in ICU (days) (range) & $16.9 \pm 22.4(3-125)$ & $40.6 \pm 38.5(0-156)$ & $22.1 \pm 18 .(2-84)$ & $23.1 \pm 21.7(3-101)$ & $23.2 \pm 23.7(2-156)$ \\
\hline Time on the ward after ICU (days) (range) $(\mathrm{n} / \mathrm{N})$ & $\begin{array}{c}8.4 \pm 5.1(2-20) \\
\quad(n=20 / 39)\end{array}$ & $\begin{array}{l}13 \pm 0(13) \\
(n=1 / 16)\end{array}$ & $\begin{array}{c}14.7 \pm 15(1-61) \\
(n=17 / 56)\end{array}$ & $\begin{array}{c}9 \pm 6.7(2-24) \\
(n=28 / 35)\end{array}$ & $\begin{array}{c}10.3 \pm 9.4(1-61) \\
(n=66 / 146)\end{array}$ \\
\hline
\end{tabular}

sd $=$ standard deviation . 
The application of methods of evaluation for patients produced the results shown below.

\section{Severity and mortality}

The mean APACHE II score recorded in the study was $20 \pm 7.3$, being a minimum score of four and a maximum of 41 , both recorded in the ICU-3. The mean estimated risk of death was $32.4 \% \pm 21.8$, ranging from 1 to $88 \%(p<0.001)$ (Table 1$)$, however, the observed mortality rate was $58.2 \%, 56.2 \%$ occurring in the ICU $(82 / 146)$ and $2 \%$ after the transfer to the wards (3/146) (Table 2). Of the deaths which occurred during the study period, 63.5\% (54/85) had an APACHE II score above $20(p<0.0001, r s=-0.52)$ (Table 2$)$, all of this $63.5 \%$ $(54 / 85)$ were over 60 years old $(p<0.0001, r s=-0.34)$ (Table 3).

The highest occurrence of discharges (30/46 $65.2 \%$ ) occurred in the groups of patients under the age of 50 years $(p<0.0001, r s=0.36)$ (Table 3$)$.

Table 2 - APACHE II score and occurrence of deaths, discharges and readmissions in the ICU. Londrina, PR, 2007

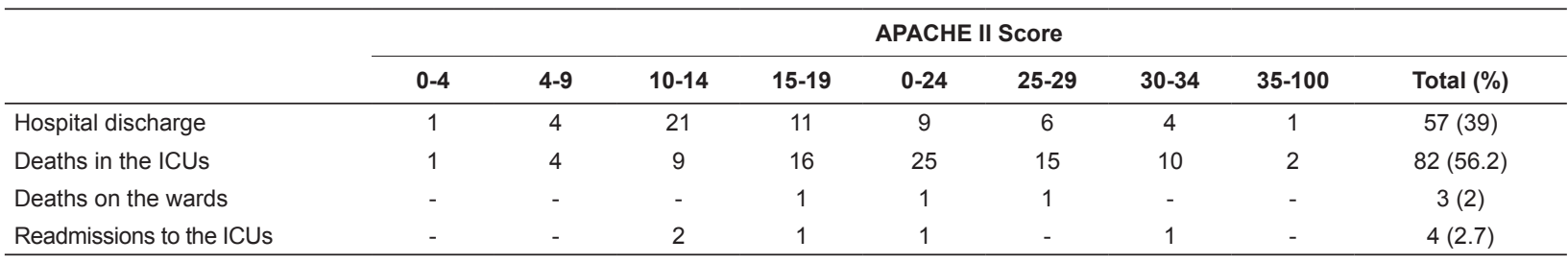

Table 3 - Ages of patients (age group) and occurrence of deaths, discharges and readmissions in ICUs. Londrina, PR, 2007

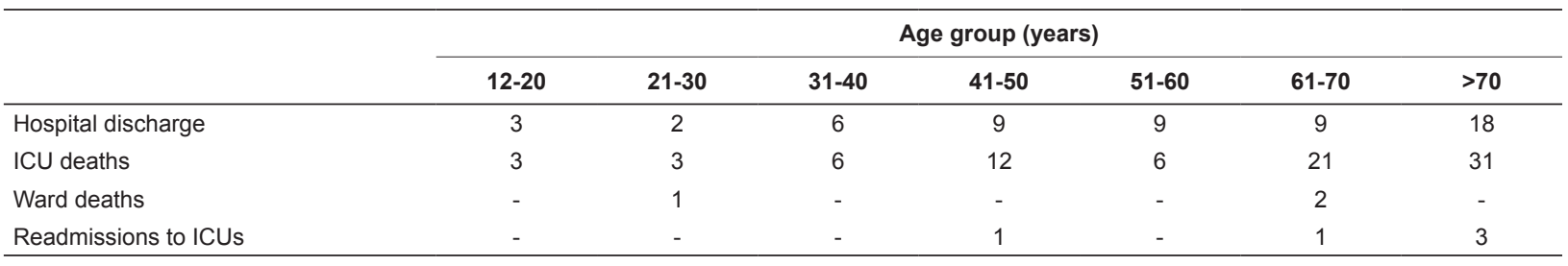

Of those patients studied, $83.5 \%$ were admitted by the ES, however, this fact did not show a statistically significant correlation relative to the estimated risk of death $(p=0.6820$, $r s=0.0342$ ). Concerning the nature of admissions, $63 \%$ of patients were in clinical treatment (non-surgical) and had a higher risk of death, between 40 and 59\% ( $p<0.0001$, $r s=0.3487$ ) (Table 4), corresponding to the APACHE II score between 20 and $29(p<0.001, r s=0.92)$.

Table 4 - Nature of admissions in relation to the estimated risk of death. Londrina, PR, 2007

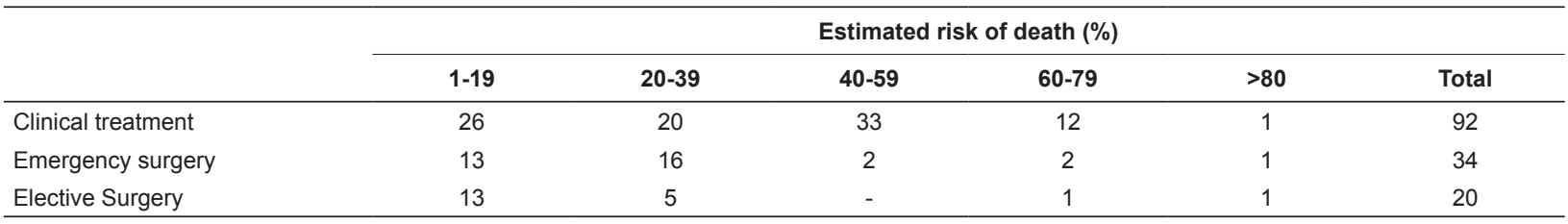

\section{Hospitalization}

In the study period, the average length of hospitalization was $27.8 \pm 25.2$ days being $23.2 \pm 23.7$ in the ICU with a two day minimum stay and maximum of 156 . Of these patients, those who were transferred to the wards $45.2 \%$ (66/146 patients) stayed on average $10.3 \pm 9.4$ days, ranging from a minimum of one and maximum of 61 days (Table 1$) ; 7.6 \%(5 / 66)$ needed to return to the ICU and $4.5 \%(3 / 66)$ died (Table 3).

The patients $(n=5)$ readmitted to the ICUs presented APACHE II scores over 10 (Table 2), with $80 \%$ $(4 / 5)$ over 60 years of age (Table 5 ). 
Table 5 - Readmission to the ICU in relation to age. Londrina, PR, 2007

\begin{tabular}{lccc}
\hline \multirow{2}{*}{ Ages } & \multicolumn{2}{c}{ Readmissions to ICUs } & Total \\
\cline { 2 - 3 } & Yes & No & \\
\hline 12 to 20 & 0 & 6 & 6 \\
21 to 30 & 0 & 6 & 6 \\
31 to 40 & 1 & 11 & 12 \\
41 to 50 & 0 & 22 & 22 \\
51 to 60 & 0 & 15 & 15 \\
61 to 70 & 0 & 33 & 33 \\
$>70$ & 4 & 48 & 52 \\
Total & 5 & 141 & 146 \\
\hline
\end{tabular}

The length of hospitalization did not show statistically significant correlation with the APACHE II score $(p=0.1805, r s=-0.114)$, nor with the length of stay in ICU $(p=0.6808, r s=0.0343)$; however, there was statistically significant correlation with the length of stay on the wards $(p<0.0001, r s=-0.4576)$.

\section{Discussion}

The lack of intensive care beds has emerged as a serious public health problem. The complexity is aggravated by the greater severity of cases admitted to philanthropic and public hospitals, extending the length of ICU stay and increasing the costs in health care.

The role of intensive care medicine is to diagnose, treat and return to the patients, who are at imminent risk of death and potentially reversible disease carriers, the functional capacity to enjoy a healthy life.

Physiotherapy has advanced its limits with knowledge and techniques, modifying the prognoses and sequelae of critical patients. Thus, the specialist in cardiopulmonary physiotherapy has been increasingly requested. Their presence in the ICU is essential to accelerate the discharge process and consequently decrease the length of hospitalization, resulting in a reduction of care costs.

The prognosis, or severity index evaluated by the APACHE II index, is used to quantify organic dysfunction, converting the patient's condition into numerical values, based on knowledge of groups of clinical alterations(7). APACHE II is a tool that has been used and tested internationally for several years and was presented by the Brazilian Ministry of Health as the index to be used to analyze the severity of adult patients admitted to ICUs, according to Decree 3432, of August 12, 1998(9).

The demographic characteristics in relation to sex and age confirm the present reality of the health systems of many countries. The number of men admitted to the
ICU was considerably higher than women. This finding is suggested by many countries where men are more commonly admitted to the ICU and are more likely to receive more aggressive support than women ${ }^{(10)}$.

Patients over 60 often have a higher likelihood of comorbidity ${ }^{(11)}$. As observed in this study, for the evaluation of the APACHE II index, patients admitted to ICUs during the study period, had a high average age, $58.2 \%$ were over 60 years old, of whom $63.5 \%$ died. Hospital discharge also showed a clear distribution when related to the number of patients in each age group in that, the main occurrence of discharge was in the groups of patients under the age of 50. In concordance with the present study, hospital stay also showed a strong association with age in a university hospital in Ceará(12).

The mean APACHE II score and the observed mortality rate $(58.2 \%)$ were high, predominantly in patients who had APACHE II score above 20. Despite this, the expected mortality rate was below the observed rate. The nature of hospitalization had considerable influence on the measurement of the APACHE II scores and the estimated risk of death, being that $63 \%$ of the patients were in clinical treatment (non-surgical). A Brazilian multicentric study that evaluated 1781 patients using APACHE II, also observed a significant difference between the expected and observed mortality rate ${ }^{(13)}$. More recently, it was demonstrated that in patients with APACHE II score higher than 18 points the mortality rate is significantly greater when compared with those with lower scores ${ }^{(14)}$. The Study BASES - Brazilian Study of Epidemiology of Sepsis, carried out in five Brazilian ICUs, found mortality rates of $11,33.9,46.9$ and $52.2 \%$ respectively in patients with systemic inflammatory response syndrome (SIRS), sepsis, severe sepsis and septic shock(15). Another Brazilian study analyzed data from 75 ICUs in different regions and found mortality rates of $16.7 \%$ for sepsis, $34 \%$ for severe sepsis and $65.3 \%$ for septic shock ${ }^{(16)}$.

Although most patients that had been admitted to the ICU originated from the ES, significant correlation between severity and length of stay in the ICU was not demonstrated. The combined analysis of four ICUs, one of them an ICU-2, characterized by long-stay patients - almost twice as long as the other ICUs studied - may explain the long hospital stay when compared with results from studies conducted in other ICUs in Brazil. A study, developed in 2004, revealed an association between increased length of stay in ICU and severity, measured by the APACHE II because those transferred to the ICU 
from the clinical or surgical wards, represent a clinical challenge ${ }^{(17)}$. In another, the authors concluded that patients transferred from wards to the ICU constituted 20 to $60 \%$ of intra-hospital mortality ${ }^{(18)}$. It was recently shown that the length of stay in the ICU of a hospital in Ceará was at least five days and not more than 163, with an average of nine days ${ }^{(12)}$.

The ICUs of the institution studied are classified by clinical characteristics and severity of clinical symptoms of their patients, i.e. ICU-2 is for the most severe patients, who proportionally represent the most hospitalization time. However, during the study period, only one patient in the ICU-2 was transferred to the ward, with a statistically significant relationship between length of stay of patients who were transferred from the ICU and APACHE II score, as already demonstrated by some authors ${ }^{(19-20)}$.

In view of the deaths occurring on the wards after transfer from the ICU, it was noted that despite being more complex cases, the determining factor of unfavorable evolution of these patients was not early transfer. The small number of readmissions to the ICUs also allows this interpretation. Residual organic dysfunctions were considered a risk factor for readmission in a study that evaluated 15,180 patients $^{(21)}$. Acute respiratory failure was also considered the main cause of readmission to intensive care in another study(22).

\section{Conclusion}

The results documented in this study demonstrate that patients in ICUs who were being assisted with physiotherapy were predominantly male, elderly, and bore clear severity - as suggested by the mean APACHE II score $20 \pm 7.3$ or by the observed mortality (58.2\%). The observed mortality, although higher than expected $(32.4 \%)$, points to the fact that most of the patients studied originated from the ES- emergency service - for clinical treatment (non-surgical) which indicates that they were patients with greater severity.

These data are important for planning future action, to implement and enhance physiotherapy protocols in the routine, at the institution studied and elsewhere, in order to ensure quality care for patients of the unit.

\section{References}

1. NIH consensus Development Conference on critical care medicine.Crit Care Med. 1983 Jun; 11(6):466-9.

2. Young MP, Gooder VJ, McBride K, James B, Fisher ES. Inpatient transfers to the intensive care unit: delays are associated with increased mortality and morbidity. J Gen Intern Med. 2003; 18(2):77-83.

3 Costa JI, Gomes do Amaral JL, Munechika M, Juliano Y, Bezerra Filho JG. Severity and prognosis in intensive care: prospective application of the APACHE II index. Sao Paulo Med J. 1999;117(5):205-14.

4. Arabi Y, Venkatesh S, Haddad S, Al Shimemeri A, Al Malik S. A prospective study of prolonged stay in the intensive care unit: predictors and impact on resource utilization. Int J Qual Health Care. 2002; 14(5):403-10.

5. Gunningberg L. EPUAP pressure ulcer prevalence survey in Sweden: a two-year follow-up of quality indicators. J Wound Ostomy Continence Nurs. 2006; 33(3):258-66.

6. Wolverton $\mathrm{CL}$, Hobbs $\mathrm{L}$, Beeson $\mathrm{T}$, Benjamin $\mathrm{M}$, Campbell k, Forbes C. Nosocomial pressure ulcer rates in critical care: Performance improvement project. J Nurs Care Qual. 2005; 20(1):56-62.

7. Knaus WA, Zimmerman JE, Wagner DP. APACHE-acute physiology and chronic health evaluation: A physiologically based classification system. Crit Care Med. 1981; 9(8):591-7.

8.Fortaleza CR, Melo EC, Fortaleza CMCB. Nasopharyngeal colonization with methicillin-resistant staphylococcus aureus and mortality among patients in an intensive care unit. Rev. Latino-Am. Enfermagem. 2009; 17(5):677-82.

9. Ministério da Saúde (BR). Portaria n. 3432, de 12 de agosto de 1998. Estabelece critérios de classificação para as unidades de tratamento intensivo-UTI. Diário Oficial da União, Brasília, 13 ago 1998. Seção 1:108-10.

10. Fowler RA, Filate W, Hartleib M, Frost DW, Lazongas C, Hladunewich M. Sex and critical illness. Curr Opin Crit Care. 2009; 15(5):442-9.

11. Chiavone PA, Sens YA. Evaluation of APACHE II system among intensive care patients at a teaching hospital. Sao Paulo Med J. 2003; 121(2):53-7.

12. Lima REF, Cassiani SHB. Potential drug interaction in intensive care patients at a teaching hospital. Rev. Latino-Am. Enfermagem. 2009; 17(2):222-7.

13. Bastos PG, Sun $X$, Wagner DP, Wu AW, Knaus WA. Glasgow Coma Scale score in the evaluation of outcome in the intensive care unit: findings from the Acute Physiology and Chronic Health Evaluation III study. Crit Care Med. 1993; 21(10):1459-65.

14. Couto DO, Feijo CAR, Aguiar SM, Meneses FA. Characteristics of patients with systemic lupus erythematosus admitted to the intensive care unit in a brazilian teaching hospital. Rev Bras Ter Intensiva. 2008; 20(3):249-53.

15. Silva E, Pedro MA, Sogayar ACB, Mohovic T, Silva CLO, Janiszewski M, et al. Brazilian Sepsis Epidemilogical Study (BASES study). Crit Care. 2004; 8(4):R251-R260.

16. Sales Junior JA, David CM, Hatum R, Souza PCSP, Pinheiro ACTS, Friedman G, et al. Sepse Brasil: estudo epidemiológico da sepse em unidades de terapia intensiva brasileiras. Rev Bras Ter Intensiva 2006; 18(1):9-17.

17. Goldhill DR, McNarry AF, Hadjianastassiou VG, Tekkis PP. The longer patients are in hospital before Intensive Care admission the higher their mortality. Intensive Care Med. 2004; 30(10): 1908-13. 
18. Franklin C, Mathew J. Developing strategies to prevent in hospital cardiac arrest: analyzing responses of physicians and nurses in the hours before the event. Crit Care Med. 1994; 22(2):244-7.

19. Kass JE, Castriotta RJ, Malakoff F. Intensive care unit outcome in the very elderly. Crit Care Med. 1992; 20(12):1666-71.

20. Feijó CAR, Bezerra ISAM, Junior Peixoto AA, Meneses FA. Morbimortalidade do Idoso Internado na Unidade de Terapia
Intensiva de Hospital Universitário de Fortaleza. Rev Rev Bras Ter Intensiva. 2006; 18(3):263-7.

21. Metnitz PG, Fieux F, Jordan B, Lang T, Moreno R, Le Gall JR. Critically ill patients readmitted to intensive care units--lessons to learn? Intensive Care Med. 2003; 29(2):241-8.

22. Yoon KB, Koh SO, Han DW, Kang OC. Discharge decisionmaking by intensivists on readmission to the intensive care unit. Yonsei Med J. 2004; 45(2):193-8.

Received: Feb. 9 2009

Accepted: Mar. $3^{\text {rd }} 2010$ 